\title{
Design and Simulation of Electrification By Solar-Wind Hybrid System
}

\author{
Aye Ei Ei Cho, Su Su Myat Mon \\ Department of Electrical Power Engineering, \\ Technological University, Thanlyin, Myanmar
}

\begin{abstract}
With the rising energy demand and lack of infrastructure because of geographical condition of Pyin Kha Yaing Village, the whole village is still not inter-connected to National Grid System. This village is located in Ngapudaw Township, Ayarwaddy Division. The latitude and longitude of study case is 15.980992 and 94.400207 respectively. Presently, the electrification of Pyin Kha Yaing Village is carried out by steam boiler driven generator with burning of Rice-Husk. With this source, total average consumption is observed as $3.4 \mathrm{MWh} / \mathrm{D}$. Instead of steam boiler generator driven, Solar-Wind Hybrid Generation system is employed for this place. A simulation model for wind-solar hybrid system is developed using the Matlab/Simulation software. The proposed model is combination of Wind Energy System, Photovoltaic (PV) array, Converter, Battery storage and inverter. The simulation model of solarwind hybrid system for selected region is presented.
\end{abstract}

Keywords: $3 \Phi$ AC load; Battery bank; Converter; Matlab/Simulation; PV Generator; Wind Turbine

\section{INTRODUCTION:}

The interest in renewable energy has been increased over last few years, especially after global awareness regarding the hazardous effect of fossil fuel burning.[1].Energy is the source of growth and the mover for economic and social development of a nation and its people. Renewable energy is derived from natural processes that are replenished constantly [2].

A photovoltaic material is a device which can capable of converting the energy contained in photons of light in to electrical current. The photovoltaic use semiconductor material for conversion of sunlight into electricity .PV cells do not use the suns heat to produce electricity rather they produce electricity directly when sunlight interacts with semiconductor materials in the PV cells [4].For increasing both voltage and current level, solar cell need to be connected both in series and parallel combination [6].Wind energy conversion system is used to capture the energy of wind to convert into electrical energy. Wind part consists of asynchronous generator and wind turbine. Asynchronous generator is basically user friendly and efficiency is good. Wind turbine requires to be kept in such a position so that it can get enough wind velocity and minimum density. In this thesis wind and solar energy makes a hybrid system. Hybrid system means more than one energy conversion system is included. The devices of this hybrid systems are PV array, boost converter, Maximum Power Point Tracker(MPPT)by using Perturb and Observe method, harmonic reducing filter, IGBT switch, three level bridge inverter, Voltage source converter(VSC),Asynchronous Generator, wind turbine and power factor correction capacitor.

The photovoltaic array is a $1000 \mathrm{~kW}$ subsystem. It is connected to three phase AC load through a DC-AC inverter where a P\&O MPPT controller is applied. Furthermore, the wind turbine subsystem is a $330 \mathrm{~kW}$ and it is equipped with a SEIG generator. The both systems of renewable energy are connected in parallel to power a common three phase AC load.

Here, the both systems of renewable energy (photovoltaic generator and the wind turbine system) are designed and simulated in section II and III. The designing and simulation of the hybrid power system 
International Journal of Trend in Scientific Research and Development (IJTSRD) ISSN: 2456-6470

is carried out in section IV. Finally, the conclusion is given in the last section.

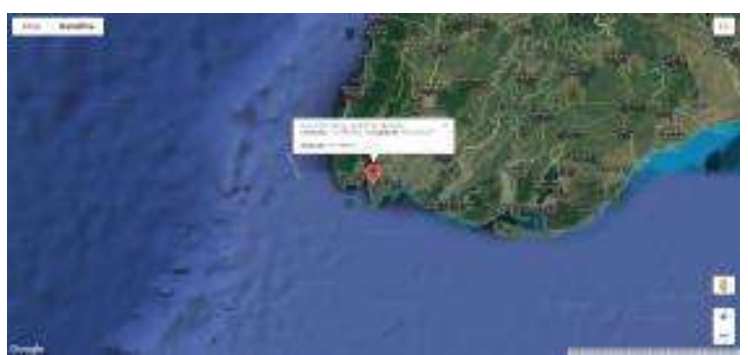

Figure (1) Location of the Pyin kha Yaing Village

\section{DESIGNING AND SIMULATION OF THE PHOTOVOLTAIC GENERATORS}

This section is devoted to simulate the PV generator using MATLAB/Simulink environment.

\section{A. Designing of the photovoltaic generator}

The characteristics of the photovoltaic model SunPower SPR-400E WHT-D are given in table I. The required daily average energy demand:

\section{$\mathrm{E}_{\mathrm{rd}}=\mathrm{E}_{\mathrm{d}} /\left(\eta_{\text {bat }} \eta_{\text {inv }} \eta_{\mathrm{c}}\right)$ \\ $\mathrm{E}_{\mathrm{rd}}=4859 \mathrm{kWH} /(0.95 \times 0.90 \times 0.98$ $=5799.02 \mathrm{kWH}$}

where,Ed = the daily average energy demand $S$ in watt hours

The average peak power:

$$
\begin{aligned}
\mathrm{P}_{\text {ave,peak }} & =\mathrm{E}_{\text {rd }} / \mathrm{T}_{\text {sh }} \\
\mathrm{P}_{\text {ave,peak }} & =5799.02 \mathrm{kWH} / 6 \\
& =966.5 \mathrm{~kW}
\end{aligned}
$$

where, $\quad$ Tsh= the peak sun hours (hrs/day)

The total current of the system:

$$
\begin{aligned}
\mathrm{I}_{\mathrm{dc}} & =\mathrm{P}_{\text {ave,peak }} / \mathrm{V}_{\mathrm{dc}} \\
\mathrm{I}_{\mathrm{dc}} & =966.5 \mathrm{~kW} / 600 \\
& =1.61 \mathrm{kA}
\end{aligned}
$$

The number of modules in series:

$$
\begin{aligned}
& \mathrm{N}_{\mathrm{sm}}=\mathrm{V}_{\mathrm{dc}} / \mathrm{V}_{\mathrm{rm}} \\
& \mathrm{N}_{\mathrm{sm}}=600 / 72.9=8 \text { numbers }
\end{aligned}
$$

The number of parallel modules strings:

$$
\begin{aligned}
\mathrm{N}_{\mathrm{pm}} & =\mathrm{I}_{\mathrm{dc}} / \mathrm{I}_{\mathrm{rm}} \\
\mathrm{N}_{\mathrm{pm}} & =1.61 \mathrm{kA} / 5.49=293.26 \text { numbers } \\
& =293 \text { numbers }
\end{aligned}
$$

Where, $\quad V_{\mathrm{dc}}=$ the dc voltage of the system $\mathrm{V}_{\mathrm{rm}}=$ the rated voltage of each module

\section{TABLE I. CHARACTERISTICS OF THE PHOTOVOLTAIC ARRAY}

\begin{tabular}{|l|l|}
\hline $\begin{array}{l}\text { Short circuit current } \\
\text { (Isc) }\end{array}$ & $5.87 \mathrm{~A}$ \\
\hline $\begin{array}{l}\text { Open circuit voltage } \\
\text { (Voc) }\end{array}$ & $85.3 \mathrm{~V}$ \\
\hline $\begin{array}{l}\text { Voltage at maximum } \\
\text { power point Vpm } \\
\text { (V) }\end{array}$ & $72.9 \mathrm{~V}$ \\
\hline Maximum power & $400.221 \mathrm{~W}$ \\
\hline $\begin{array}{l}\text { Current at maximum } \\
\text { power point Ipm(A) }\end{array}$ & $5.49 \mathrm{~A}$ \\
\hline Solar Insolation & $1000 \mathrm{~W} / \mathrm{m}^{2}$ \\
\hline Filter Inductor & $003 \mu \mathrm{H}$ \\
\hline $\begin{array}{l}\text { Nominal Solar Array } \\
\text { voltage }\end{array}$ & $680 \mathrm{~V}$ \\
\hline Input Voltage & $600 \mathrm{~V}$ \\
\hline DC link Capacitor & $0.0138 \mathrm{~F}$ \\
\hline
\end{tabular}

The photovoltaic array is coupled with the following parts:

-DC/AC inverter (controlled by a P\&O MPPT technique)

-AC load (Three phase).

Furthermore, it has two input parameters: the solar irradiation and the ambient temperature.

\section{SIMUlation OF THE WIND TURBINE SYSTEM}

In another way, the wind turbine is considered as an important system of renewable energy [23].Generally, it is composed by:

-Wind turbine.

-SEIG generator

-6 Pulse Rectifiers

\section{A. Designing of the wind turbine system}

The characteristic of the Enercon E33 model wind turbine is used. The SEIG _WT system used for this simulation has the following characteristics: $330 \mathrm{~kW}$; 400V; $50 \mathrm{~Hz}$ and its parameters are given in Table II.

The total number of modules:

$$
\begin{aligned}
& \mathrm{N}_{\mathrm{tm}}=\mathrm{N}_{\mathrm{sm}} \times \mathrm{N}_{\mathrm{pm}} \\
& \mathrm{N}_{\mathrm{tm}}=8 \times 293=2344 \text { numbers }
\end{aligned}
$$


International Journal of Trend in Scientific Research and Development (IJTSRD) ISSN: 2456-6470

TABLE II. THE CHARACTERISTICS OF THE WIND TURBINE SYSTEM

\begin{tabular}{|l|c|}
\hline $\begin{array}{l}\text { Nominal phase to phase } \\
\text { voltage } \mathrm{V}_{\mathrm{n}}\left(\mathrm{V}_{\mathrm{rms}}\right)\end{array}$ & $400 \mathrm{~V}$ \\
\hline $\begin{array}{l}\text { Nominal frequency } \\
\mathrm{f}_{\mathrm{n}}\left(\mathrm{H}_{\mathrm{z}}\right)\end{array}$ & $50 \mathrm{H}_{\mathrm{z}}$ \\
\hline $\begin{array}{l}\text { LC Filter for } 6 \text { Pulse } \\
\text { Rectifier(Filter } \\
\text { Inductance) }\end{array}$ & $61.43 \mu \mathrm{F}$ \\
\hline $\begin{array}{l}\text { LC filter for } 6 \text { pulse } \\
\text { Rectifier(Filter } \\
\text { Capacitor) }\end{array}$ & $18.3 \mathrm{mF}$ \\
\hline Wind Speed & $10 \mathrm{~m} / \mathrm{s}$ \\
\hline Wind Energy & $564.3 \mathrm{kWh}$ \\
\hline
\end{tabular}

\section{DESIGNING OF THE BATTERY}

The estimate energy storage:

$$
\begin{aligned}
\mathrm{E}_{\text {est }} & =\mathrm{E}_{\mathrm{d}} \times \mathrm{D}_{\text {aut }} \text { Internatio } \\
& =5423.3 \mathrm{kWh} \times 2=10846.6 \mathrm{kWh}
\end{aligned}
$$

The safe energy storage:

$$
\begin{aligned}
\mathrm{E}_{\text {safe }} & =\mathrm{E}_{\text {est }} / \mathrm{D}_{\text {dish }} \\
& =10846.6 \mathrm{kWH} / 0.8 \\
& =13558.25 \mathrm{kWH}
\end{aligned}
$$

The total capacity of the battery bank in amperehours:

$$
\begin{aligned}
\mathrm{C}_{\mathrm{tb}} & =\mathrm{E}_{\mathrm{safe}} / \mathrm{V}_{\mathrm{b}} \\
& =13558.25 \mathrm{kWH} / 2=6779125 \mathrm{Ah}
\end{aligned}
$$

The total number of battery:

$$
\begin{aligned}
\mathrm{N}_{\mathrm{tb}} & =\mathrm{C}_{\mathrm{tb}} / \mathrm{C}_{\mathrm{b}} \\
& =6779125 / 1000 \\
& =6779.125 \text { numbers }
\end{aligned}
$$

The no.of batteries in series:

$$
\begin{aligned}
\mathrm{N}_{\mathrm{sb}} & =\mathrm{V}_{\mathrm{dc}} / \mathrm{V}_{\mathrm{b}} \\
& =760 / 2=380 \text { numbers }
\end{aligned}
$$

The no.of batteries in parallel:

$$
\begin{aligned}
\mathrm{N}_{\mathrm{pb}} & =\mathrm{N}_{\mathrm{tb}} / \mathrm{N}_{\mathrm{sb}} \\
& =6780 / 380=17.8=18 \text { numbers }
\end{aligned}
$$

Where, $\quad \mathrm{D}_{\mathrm{aut}}=$ the number of autonomy days depth of discharge batteries in Ah

$\mathrm{C}_{\mathrm{b}}=$ the capacity of the selected

TABLE III. CHARACTERISTICS OF IGBT Pulse Width Modulation Inverter

\begin{tabular}{|l|l|}
\hline Filter Capacitor & $944.98 \mu \mathrm{F}$ \\
\hline Filter Inductance & $4.558 \mathrm{mH}$ \\
\hline Inverter rating & $1140 \mathrm{~kW}$ \\
\hline & \\
\hline
\end{tabular}

\section{Load Profile Input}

The village loads are consumed for the households and the communal applications. There are 2300 households and the population is about 9820. The existing Biomass (Rice-Husk) power plant can supply 500 households and the SHS (Solar Home Systems) are installed in 100 households. The remaining 1400 households are un-electrified. Therefore, in this HOMER model, the PV Hybrid system is considered to supply the whole village.

The households are divided into low income, medium income, and high income households. These loads $(\mathrm{kW})$ are mentioned in Table 1.

TABLE IV. Household Types and Loads

\begin{tabular}{|l|l|l|}
\hline Household Types & Amount & $\begin{array}{l}\text { Load } \\
\text { (kW) }\end{array}$ \\
\hline Low income & 1300 & 208 \\
\hline Medium income & 700 & 437.5 \\
\hline High income & 300 & 256.5 \\
\hline
\end{tabular}

The communal facilities include the schools (high, medium, and primary), the monasteries, the hospital, and the street lamps. These loads $(\mathrm{kW})$ of the communal facilities are described in Table 2.

Then, the total load is about $950.32 \mathrm{~kW}$ for the whole village. Fig. 9 shows the load profile inputs. The annual average is $3.4 \mathrm{MWh} /$ day and the peak load is $950 \mathrm{~kW}$. 
International Journal of Trend in Scientific Research and Development (IJTSRD) ISSN: 2456-6470

TABLE V. Communal Facilities and Load

\begin{tabular}{|l|l|c|}
\hline $\begin{array}{l}\text { Communal } \\
\text { Facilities }\end{array}$ & Amount & $\begin{array}{l}\text { Load } \\
(\mathrm{kW})\end{array}$ \\
\hline School & 3 & 10.17 \\
\hline Monastery & 3 & 10.56 \\
\hline Hospital & 1 & 3.59 \\
\hline Street Lamp & 600 & 24 \\
\hline
\end{tabular}

\section{Proposed Solar-Wind Hybrid Model}

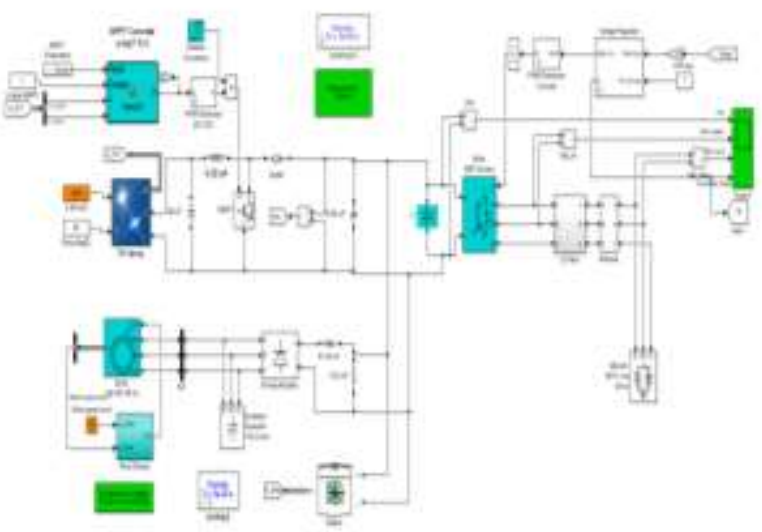

Figure(2) Solar-Wind Hybrid Systemev of

Figure (3) Measurement System

\section{Simulation Results}

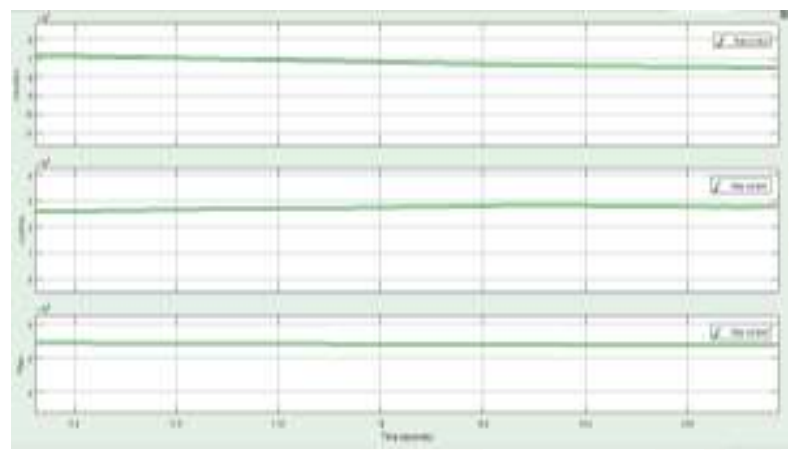

Figure(4) $V_{p v}-I_{p v}-P_{p v}$ output curve Matlab/Simulation
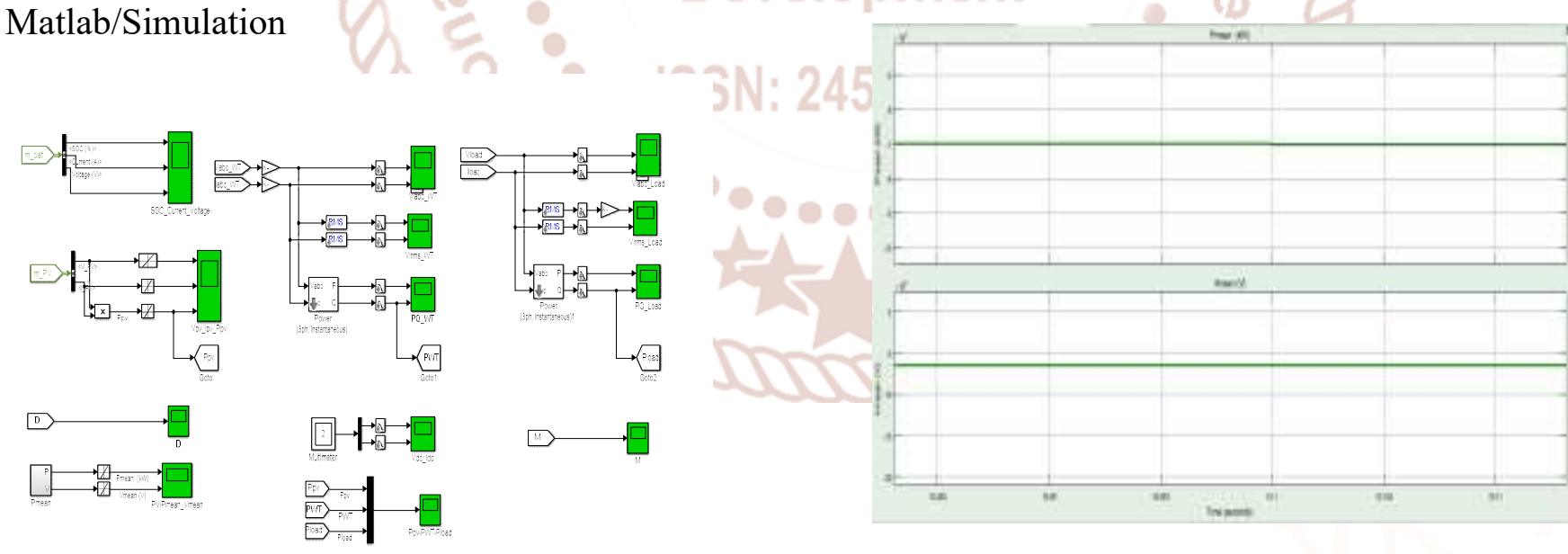

Figure(6) $\mathrm{P}_{\text {mean }}$ and $\mathrm{V}_{\text {mean }}$ for $\mathrm{PV}$ 
International Journal of Trend in Scientific Research and Development (IJTSRD) ISSN: 2456-6470

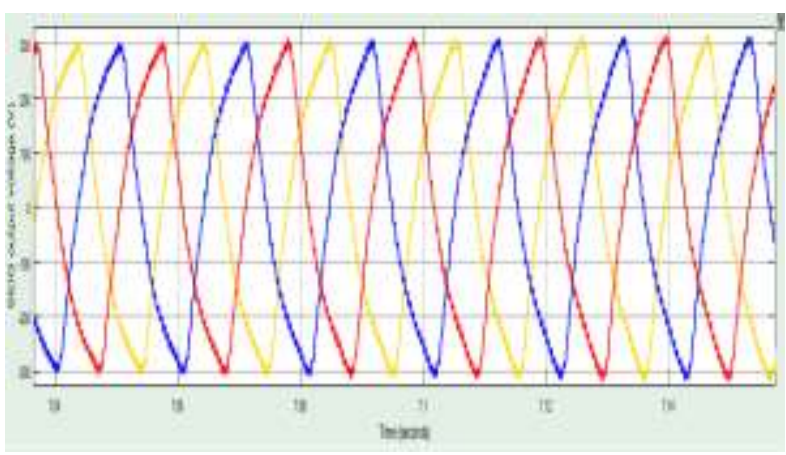

Figure(7) Self Excited Induction Generator output voltage(WT)

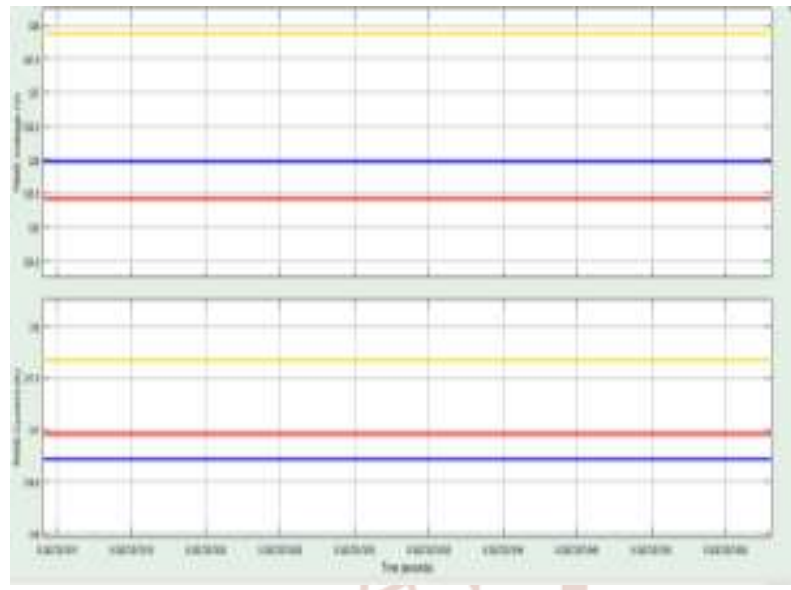

Figure(8) RMS Voltage and RMS Current for WT

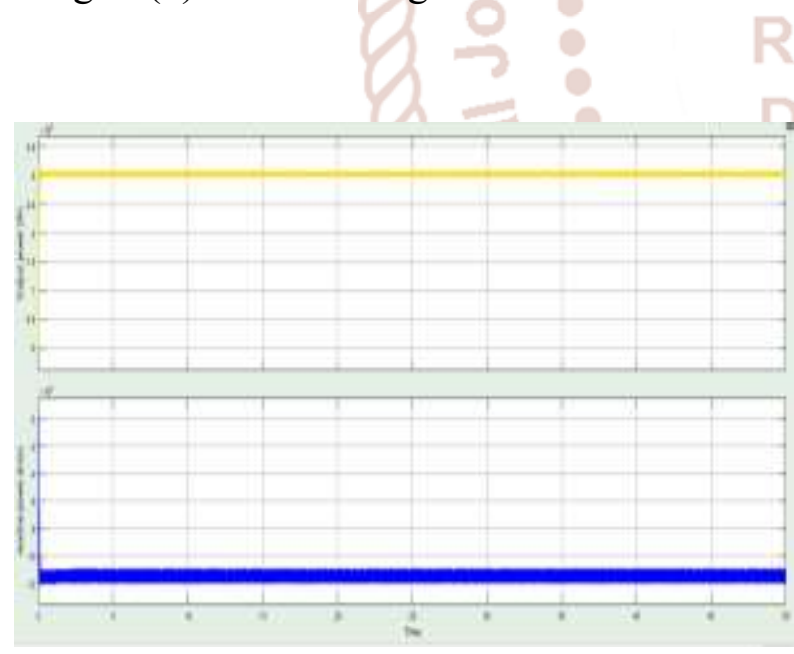

Figure(9) Real Power and Reactive Power for WT

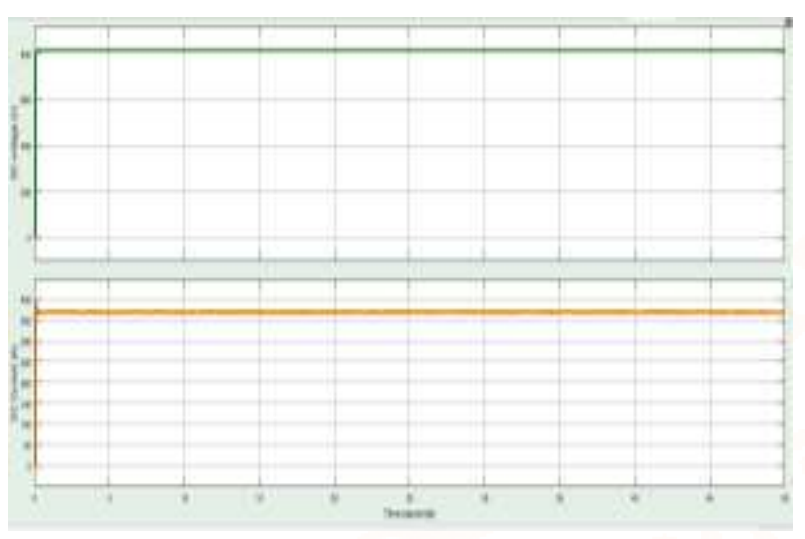

Figure $(10) \mathrm{V}_{\mathrm{dc}}$ and $\mathrm{I}_{\mathrm{dc}}$ curve

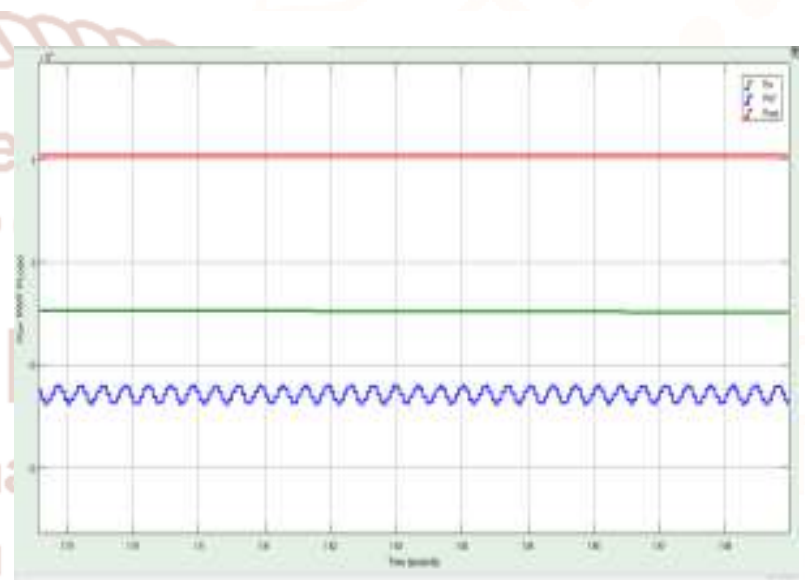

Figure(11) $\mathrm{P}_{\mathrm{pv}}-\mathrm{P}_{\mathrm{wT}}-\mathrm{P}_{\text {load }}$ curve

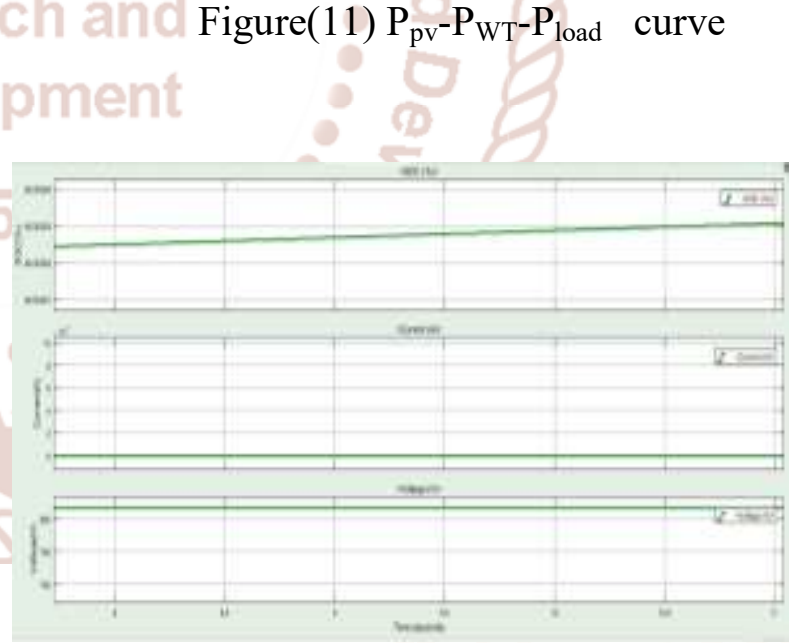

Figure(12) The State of Charge of the Battery 


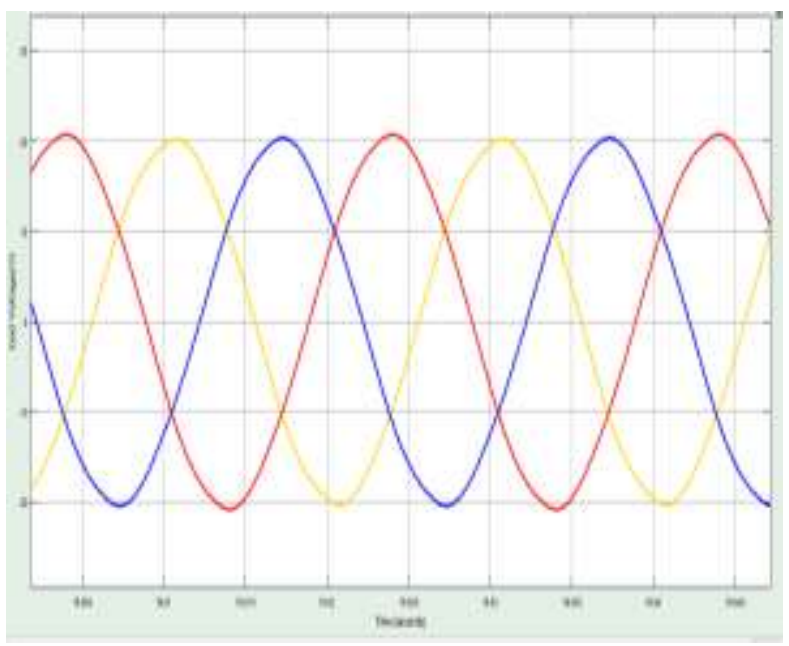

Figure(13 AC Output Voltage of the Load

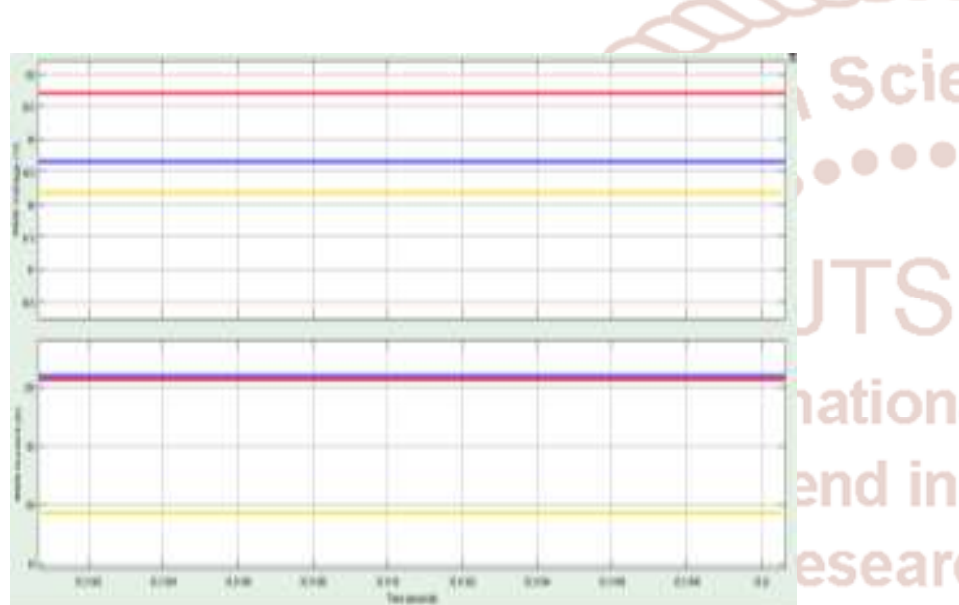

Figure(14) RMS Voltage and RMS Current for Load

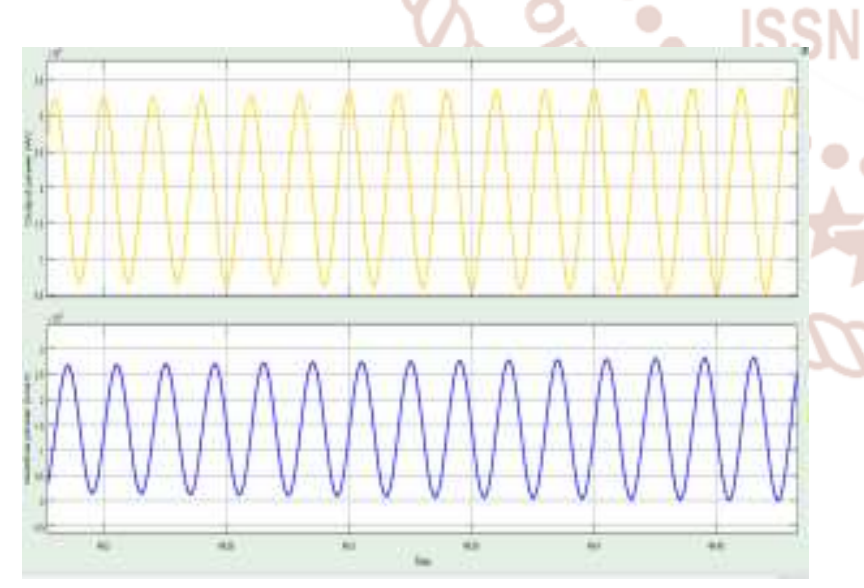

Figure(15) Real Power and Reactive Power for Load

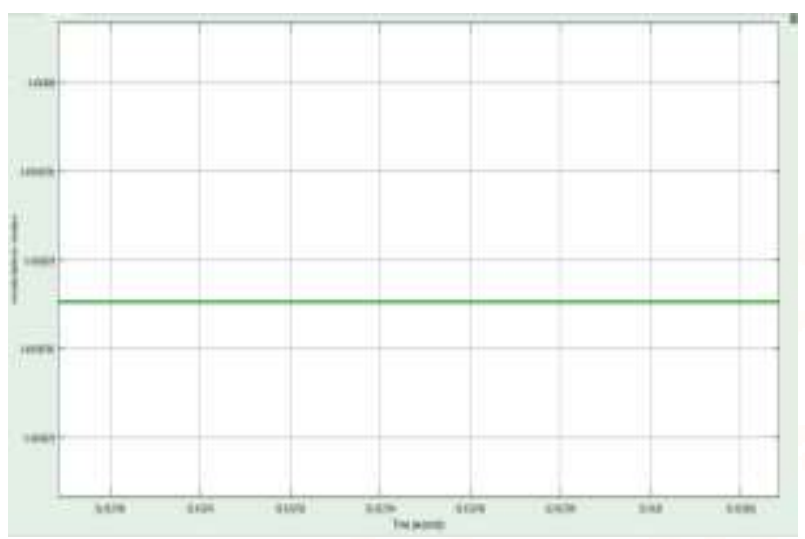

Figure(16) Modulation Index for IGBT PWM Inverter
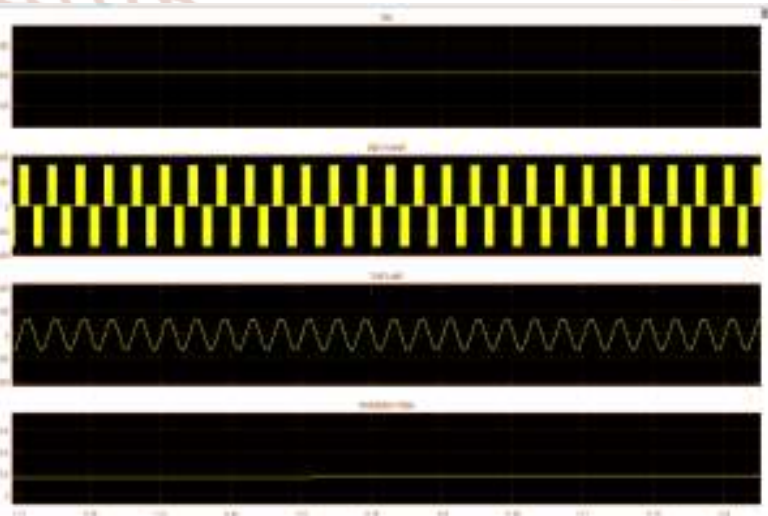

Figure(17) $\mathrm{V}_{\mathrm{dc}}, \mathrm{V}_{\mathrm{ab}}$ inverter, $\mathrm{V}_{\mathrm{ab}}$ load, modulation index

\section{IV.CONCLUSION}

Hybrid energy system significantly improves efficiency and sustainability of a power system. The penetration of renewable power sources, selection and combination of efficient energy to supply a remote community has been investigated in this work. In this study, a model is proposed for the supply of the demand having components PV array, Wind turbine, converter, battery bank and inverter. HOMER software simulated a number of configurations and the optimal solution is found. This study has been performed at specific region with variation in region, geographical condition, equipment cost and electricity tariff configuration can vary. This also gives a clean and a sustainable future.

\section{ACKNOWLEDGMENT}

I would like to thank all of my teachers in Electrical Power Engineering Department for their supporting, for encouragement, useful suggestions, invaluable guidance and help till the completion of this paper. 


\section{REFERENCES}

1) Bowman, M., Debray, S. K., and Peterson, L. L. 1993. Reasoning about naming systems. .

2) Ding, W. and Marchionini, G. 1997 A Study on Video Browsing Strategies. Technical Report. University of Maryland at College Park.

3) Fröhlich, B. and Plate, J. 2000. The cubic mouse: a new device for three-dimensional input. In Proceedings of the SIGCHI Conference on Human Factors in Computing Systems

4) Tavel, P. 2007 Modeling and Simulation Design. AK Peters Ltd.

5) Sannella, M. J. 1994 Constraint Satisfaction and Debugging for Interactive User Interfaces. Doctoral Thesis. UMI Order Number: UMI Order No. GAX95-09398., University of Washington.

6) Forman, G. 2003. An extensive empirical study of feature selection metrics for text classification. J. Mach. Learn. Res. 3 (Mar. 2003), 1289-1305.

7) Brown, L. D., Hua, H., and Gao, C. 2003. A widget framework for augmented interaction in SCAPE.

8) Y.T. Yu, M.F. Lau, "A comparison of MC/DC, MUMCUT and several other coverage criteria for logical decisions", Journal of Systems and Software, 2005, in press.

9) Spector, A. Z. 1989. Achieving application requirements. In Distributed Systems, S. Mullender 